\title{
Study on $\mathrm{Cr}_{2} \mathrm{O}_{3} / \gamma-\mathrm{Al}_{2} \mathrm{O}_{3}$ Catalysts for Mixed Pyrolysis of Coal to Produce Hydrogen-Rich Fuel Gas
}

\author{
Chen Jihao $^{1,3 *}$, Li Yue ${ }^{1}$, Zhang Lei ${ }^{2}$ \\ 'Shaanxi Coal Geological Laboratory Co.,Ltd., Xi'an, 710054, China \\ ${ }^{2} \mathrm{Xi}$ 'an University of Science and Technology, Xi'an, 710054, China \\ ${ }^{3}$ Key Laboratory of Coal Resources Exploration and Comprehensive Utilization, Ministry of Natural Resources, \\ Xi'an, 710021, China
}

Received: 4 March 2021

Accepted: 13 April 2021

\begin{abstract}
$\gamma-\mathrm{Al}_{2} \mathrm{O}_{3}$ was used as the carrier, the group VIII metal oxides and the sub group metal oxides were used as active components, and the $\gamma-\mathrm{Al}_{2} \mathrm{O}_{3}$ catalysts were prepared by the equal volume impregnation method. Hydrogen rich fuel gas and tar products were produced by the mixed pyrolysis of coal and catalysts in a furnace. The influence of $\gamma-\mathrm{Al}_{2} \mathrm{O}_{3}$ catalysts with different loading $\mathrm{Cr}_{2} \mathrm{O}_{3}$ on the mixed pyrolysis products of coal was studied. The catalyst was characterized by ICP-MS, XRD and BET, and the pyrolysis mechanism of coal and catalyst was studied. The results showed that: 1) The tar and gas of coal pyrolysis were $0.32 \mathrm{~g}$ and $1.58 \mathrm{~g}$, respectively, and the highest total contents of $\mathrm{CO}, \mathrm{H}_{2}$ and $\mathrm{CH}_{4}$ were $71.40 \%$ respectively. 2) $\mathrm{Fe}_{2} \mathrm{O}_{3} / \gamma-\mathrm{Al}_{2} \mathrm{O}_{3}$ catalyst made the highest tar of $0.75 \mathrm{~g}$, which was $16.4 \%$ higher than that of coal; $\mathrm{Cr}_{2} \mathrm{O}_{3} / \gamma-\mathrm{Al}_{2} \mathrm{O}_{3}$ catalyst made the highest gas of $1.73 \mathrm{~g}$, which was $9.5 \%$ higher than that of raw coal. 3) $\mathrm{The} \mathrm{Cr}_{2} \mathrm{O}_{3} / \gamma-\mathrm{Al}_{2} \mathrm{O}_{3}$ catalyst prepared by loading $1 \% \mathrm{Cr}_{2} \mathrm{O}_{3}$ had better catalytic effect. 4) The the specific surface areas of $\mathrm{Cr}_{2} \mathrm{O}_{3} / \gamma-\mathrm{Al}_{2} \mathrm{O}_{3}$ and $\gamma-\mathrm{Al}_{2} \mathrm{O}_{3}$ were similar, while the catalytic cracking effect of $\mathrm{Cr}_{2} \mathrm{O}_{3} / \gamma-\mathrm{Al}_{2} \mathrm{O}_{3}$ was more obvious than that of $\gamma-\mathrm{Al}_{2} \mathrm{O}_{3}$, so $\mathrm{Cr}_{2} \mathrm{O}_{3}$ improved the catalytic activity.
\end{abstract}

Keywords: group VIII metal oxides, sub-group metal oxides, mixed pyrolysis, hydrogen rich fuel gas, tar

\section{Introduction}

Coal is a valuable energy resource, but also a complex compound, containing many kinds of chemical substances, and a variety of chemical raw materials can be refined through pyrolysis coal. In the process of coal pyrolysis, tar, pyrolytic gas and pyrolytic

*e-mail: 15929995059@163.com coke are mainly produced [1]. At the same time, the utilization efficiency and comprehensive utilization value of coal can be improved by pyrolysis, and the environmental pollution caused by direct combustion can also be reduced [2]. The main components of coal pyrolysis gas are $\mathrm{O}_{2}, \mathrm{~N}_{2}, \mathrm{H}_{2}, \mathrm{CO}, \mathrm{CO}_{2}, \mathrm{CH}_{4}, \mathrm{CnH}_{\mathrm{m}}$ and so on. The combustible gases which can be used in pyrolysis gas are $\mathrm{H}_{2}, \mathrm{CO}, \mathrm{CH}_{4}$ and so on. They can be used as industrial fuel for power generation and city gas. The pyrolysis gas products and yields 
of coal are quite different due to the different types and pyrolysis conditions of coal. The composition and distribution of pyrolysis products vary with the degree of coalification, the structure and properties of coal, and the $\mathrm{H} / \mathrm{C}, \mathrm{O} / \mathrm{C}$, fixed carbon and volatile matter in coal. The activation energy increased with the increase of the degree of coalification and the temperature at the beginning of pyrolysis [3]. The pyrolysis temperature is the main external factor that affects the coal pyrolysis. When the pyrolysis temperature rises, the pyrolysis gas yield increases, but the solid coke and pyrolysis tar yield decreases correspondingly. The effect of pyrolysis temperature on the pyrolysis gas of lignite at low temperature [4]. The results showed that with the increase of pyrolysis temperature, the yields of $\mathrm{CO}$ and $\mathrm{CO}_{2}$ increased first and then decreased, while the yields of $\mathrm{CH}_{4}$ and $\mathrm{H}_{2}$ increased gradually. At higher temperature, the prolongation of the residence time will increase the degree of the secondary reaction and influence the distribution of pyrolytic products [5]. The pressure in the pyrolysis system of coal will affect the mass transfer process in the pyrolysis process, and the increase of the pressure will increase the resistance of the release of the primary volatiles, prolong the residence time, and lead to the intensification of the secondary reaction of the volatiles [6]. The yield of catalyst gas is the most important factor, which can increase the content of combustible gas in pyrolysis gas and improve the quality of coal tar to some extent [7]. The results showed that the main components of pyrolysis gas were $\mathrm{H}_{2}, \mathrm{CO}, \mathrm{CO}_{2}, \mathrm{CH}_{4}$ and $\mathrm{CnHm}$, and each component of pyrolysis gas was produced by pyrolysis and polycondensation of specific functional groups in coal. Among them, $\mathrm{CO}$ and $\mathrm{CO}_{2}$ were related to the oxygencontaining functional groups in coal; hydrocarbon gas was related to the side chain of fat; it was mainly related to the condensation reaction. At low temperature, $\mathrm{CO}_{2}$ mainly produced in the cracking of carboxyl, carbonyl and ester groups, while $\mathrm{CO}$ mainly produced in the cracking of carbonyl groups; at high temperature, $\mathrm{CO}_{2}$ mainly produced in the relatively stable oxygencontaining functional groups (ether, quinone, oxygencontaining heterocycle, etc.) and carbonate minerals, while CO mainly produced in the cracking of quinone, ester ether, aromatic ether and phenol hydroxyl [8]. At low temperature, $\mathrm{CH}_{4}$ produced by the breaking of methoxy group in aromatic side chain; when the temperature rised to $500-550^{\circ} \mathrm{C}, \mathrm{CH}_{4}$ produced by the breaking of methylene bridge bond and methyl; at high temperature, $\mathrm{CH}_{4}$ produced by the breaking of aromatic heterocycle and hydrogen carbon reaction [9]. The amount of pyrolysis gas released during coal pyrolysis was very small, and $\mathrm{CnHm}$ mainly came from aromatic aliphatic side chain fracture, cracking and condensation of aliphatic hydrocarbons [10]. Compared with other pyrolysis gas components, $\mathrm{H}_{2}$ was generated at a higher temperature, and it generated at about $400^{\circ} \mathrm{C}$. Most researchers believed that $\mathrm{H}_{2}$ mainly came from coal dehydrogenation (condensation of organic matter, cyclization and aromatization of alkanes) and reaction with water [11], and some scholars believed that it also came from the reaction of water gas at high temperature [12].

At present, there was many kinds of catalysts for coal catalytic pyrolysis, many of which have excellent performance and can be used in industrial production are composed of catalyst carrier and active components. The support of the catalyst can ensure that the catalyst is suitable for different catalytic environments, and the active component can ensure the catalytic efficiency of the catalyst. $\gamma-\mathrm{Al}_{2} \mathrm{O}_{3}$ has excellent physical and chemical properties [13], and can maintain high mechanical properties in different catalytic environments. As a carrier for preparing catalyst, it is very suitable for experimental operation and industrial application. There are many kinds of active components in catalysts. The selection of metal oxides is mainly in alkali metal oxides [14], alkaline earth metal oxides [15], by-group metal oxides [16] and the eighth group metal oxides [17]. Metal oxides are widely used as active components of catalysts, and have directional control effect on coal pyrolysis products. Therefore, the preparation of excellent catalyst is very important for the production and quality of combustible gas from coal pyrolysis.

In this study, $\gamma-\mathrm{Al}_{2} \mathrm{O}_{3}$ was used as the carrier to prepare the catalyst, and group VIII and sub-group metal oxides were used as the active components to support $\gamma-\mathrm{Al}_{2} \mathrm{O}_{3}$ to prepare the supported catalyst. The effect of the catalyst on the oil and gas production in the process of coal pyrolysis catalytic cracking was studied, and a kind of industrial application supported $\gamma-\mathrm{Al}_{2} \mathrm{O}_{3}$ catalyst with high catalytic efficiency was prepared, so as to improve the efficiency of coal pyrolysis production and the quality of hydrogen rich fuel gas.

\section{Material and Methods}

\section{Materials and Drugs}

The coal used in the experiment was produced in Cuimu Coal Mine, Shaanxi, with a particle size of $3 \sim 5 \mathrm{~mm}$. Table 1 shows the results of industrial analysis and elemental analysis of the coal sample. $\gamma-\mathrm{Al}_{2} \mathrm{O}_{3}$ was purchased on the market with a particle size of $3 \sim 5 \mathrm{~mm}$. $\mathrm{Fe}\left(\mathrm{NO}_{3}\right)_{3} \cdot 9 \mathrm{H}_{2} \mathrm{O}, \quad \mathrm{Co}\left(\mathrm{NO}_{3}\right)_{2} \cdot 6 \mathrm{H}_{2} \mathrm{O}$, $\mathrm{Ni}\left(\mathrm{NO}_{3}\right)_{2} \cdot 6 \mathrm{H}_{2} \mathrm{O}, \mathrm{Cu}\left(\mathrm{NO}_{3}\right)_{2} \cdot 3 \mathrm{H}_{2} \mathrm{O},\left(\mathrm{CH}_{2} \mathrm{COO}\right)_{2} \mathrm{Zn} \cdot 2 \mathrm{H}_{2} \mathrm{O}$, $\left(\mathrm{NH}_{4}\right)_{6} \mathrm{Mo}_{7} \mathrm{O}_{24} \cdot 4 \mathrm{H}_{2} \mathrm{O}, \quad \mathrm{Cr}\left(\mathrm{NO}_{3}\right)_{3} \cdot 9 \mathrm{H}_{2} \mathrm{O}$ and $\mathrm{Mn}\left(\mathrm{NO}_{3}\right)_{2} \cdot 4 \mathrm{H}_{2} \mathrm{O}$ were all analytically pure.

\section{Preparation of Catalysts}

(1) Preparation of $\gamma-\mathrm{Al}_{2} \mathrm{O}_{3}$ supported subgroup metal oxide catalyst: By constant volume impregnation, $3 \mathrm{~g} \gamma-\mathrm{Al}_{2} \mathrm{O}_{3}$ was immersed in $5 \% \mathrm{Fe}\left(\mathrm{NO}_{3}\right)_{3}$ solution for $24 \mathrm{~h}$. It was taken out and placed in a muffle 
Table 1. Industrial analysis and elemental analysis of coal samples (\%).

\begin{tabular}{|c|c|c|c|c|c|c|c|c|}
\hline \multicolumn{4}{|c|}{ Industrial analysis } & \multicolumn{5}{c|}{ Elemental analysis } \\
\hline Mad & Aad & Vad & FCad & C & H & O & N & S \\
\hline 4.99 & 11.87 & 32.79 & 50.35 & 67.64 & 3.63 & 27.53 & 0.67 & 0.53 \\
\hline
\end{tabular}

furnace and roasted at $450^{\circ} \mathrm{C}$ for $4 \mathrm{~h}$. It was removed as $\mathrm{Fe}_{2} \mathrm{O}_{3} / \gamma-\mathrm{Al}_{2} \mathrm{O}_{3}$ catalyst with 5\% loading. $\mathrm{Co}_{2} \mathrm{O}_{3} / \gamma-$ $\mathrm{Al}_{2} \mathrm{O}_{3}$ and $\mathrm{Ni}_{2} \mathrm{O}_{3} / \gamma-\mathrm{Al}_{2} \mathrm{O}_{3}$ catalysts with $5 \%$ loading were prepared by the same method.

(2) Preparation of $\gamma-\mathrm{Al}_{2} \mathrm{O}_{3}$ supported group VIII metal oxide catalyst: By constant volume impregnation, $3 \mathrm{~g} \gamma-\mathrm{Al}_{2} \mathrm{O}_{3}$ was immersed in $5 \% \mathrm{Cu}\left(\mathrm{NO}_{3}\right)_{2}$ solution for $24 \mathrm{~h}$. It was taken out and placed in a muffle furnace and roasted at $450^{\circ} \mathrm{C}$ for $4 \mathrm{~h}$. It was removed as $\mathrm{CuO} / \gamma-\mathrm{Al}_{2} \mathrm{O}_{3}$ catalyst with $5 \%$ loading. $\mathrm{ZnO} / \gamma-\mathrm{Al}_{2} \mathrm{O}_{3}$, $\mathrm{Mo}_{2} \mathrm{O}_{3} / \gamma-\mathrm{Al}_{2} \mathrm{O}_{3}, \quad \mathrm{Cr}_{2} \mathrm{O}_{3} / \gamma-\mathrm{Al}_{2} \mathrm{O}_{3}$ and $\mathrm{Mn}_{2} \mathrm{O}_{3} / \gamma-\mathrm{Al}_{2} \mathrm{O}_{3}$ catalysts with $5 \%$ loading were prepared by the same method.

(3) Preparation of $\mathrm{Cr}_{2} \mathrm{O}_{3} / \gamma-\mathrm{Al}_{2} \mathrm{O}_{3}$ catalysts with different loading loads: By constant volume impregnation, $3 \mathrm{~g} \gamma-\mathrm{Al}_{2} \mathrm{O}_{3}$ was immersed in $1 \%, 5 \%$ and $11 \% \mathrm{Cr}\left(\mathrm{NO}_{3}\right)_{3}$ solution for $24 \mathrm{~h}$. It was taken out and placed in a muffle furnace and roasted at $450^{\circ} \mathrm{C}$ for $4 \mathrm{~h}$. It was removed as $\mathrm{Cr}_{2} \mathrm{O}_{3} / \gamma-\mathrm{Al}_{2} \mathrm{O}_{3}$ catalyst with $1 \%$, $5 \%$ and $11 \%$ loading.

\section{Activity Evaluation of Catalyst}

In the experiment, in the coal pyrolysis cracking catalytic system, $15 \mathrm{~g}$ coal sample and $3 \mathrm{~g}$ catalyst were mixed and placed at furnace was vacant. First, the coal undergoes a catalytic pyrolysis reaction, and the resulting pyrolysis product entered the tar collector. The liquid phase components of the catalytic pyrolysis were collected, and the gas phase components were dried. The gas was collected and detected by the gas collector. The dried gas entered the flowmeter to count the volume, and then it was collected and detected. At the end of the experiment, the tar attached in the reaction tube and condensation tube was washed with acetone, and all acetone solutions containing tar were collected together. The water in tar was collected by anhydrous sodium sulfate, and then the acetone was removed by rotary evaporation, and the tar was collected and weighed. The gas components were detected by gas chromatography, and the changes of gas and tar components were analyzed. In this paper, the effect of catalyst was evaluated by the change of pyrolysis products of bituminous coal.

\section{Detection of Pyrolysis Products}

The gas produced by catalytic cracking of tar was collected by gas collecting bag and analyzed by GC-2014c gas chromatography. The working conditions of gas chromatography were shown in Table 2 below.

\section{Characterization}

The Vario EL III element analyzer (Elementar company in Germany) was used for elemental detection of coal samples.

Specific surface area (BET): The JW-BK122W type surface and pore size analyzer is used to measure the specific surface area of different types of the catalysts.

X-ray analysis (XRD, Beijing General Analysis Instrument Co., Ltd.): XD-3 type ray diffractometer; the test parameters: the voltage is $36 \mathrm{KV}$, the current is $20 \mathrm{~mA}$, the target is $\mathrm{Cu}, \mathrm{K}$ alpha rays, $2 \theta / \theta$ is $5^{\circ}$ to $80^{\circ}$, and scanning speed is $4\left(^{\circ}\right) / \mathrm{min}$.

Inductively coupled plasma mass spectrometer (ICPMS): iCAP Q type, (Thermo Fisher Scientific, USA), working conditions, RF generator power: $1400 \mathrm{kw}$, cooling gas flow rate: $13.0 \mathrm{~L} / \mathrm{min}$, auxiliary gas flow rate: $0.72 \mathrm{~L} / \mathrm{min}$, scanning mode: peak jump, atomizer flow rate: $0.90 \mathrm{~L} / \mathrm{min}$, sampling time: $20 \mathrm{~s}$, sampling pump speed: $70 \mathrm{rpm}$, sampling depth: $150 \mathrm{~mm}$, sampling cone: $1.1 \mathrm{~mm}$, intercepting cone: $0.9 \mathrm{~mm}$, double charge production Rate: $\mathrm{IBa}++/ \mathrm{Ba}<3 \%$, oxide yield, $\mathrm{ICeO}+/ \mathrm{Ce}<3 \%$, mainly used to determine the content of catalysts.

Table 2. Operating conditions of GC.

\begin{tabular}{|c|c|c|}
\hline Detector & TCD & FID \\
\hline Chromatographic column & Stainless steel column $(3 \mathrm{~m})$ & Stainless steel column $(3 \mathrm{~m})$ \\
\hline Gasification chamber temperature $\left({ }^{\circ} \mathrm{C}\right)$ & 360 & 360 \\
\hline Column box temperature $\left({ }^{\circ} \mathrm{C}\right)$ & 80 & 80 \\
\hline Detector temperature $\left({ }^{\circ} \mathrm{C}\right)$ & 100 & 150 \\
\hline Determination of gases & & \\
\hline
\end{tabular}




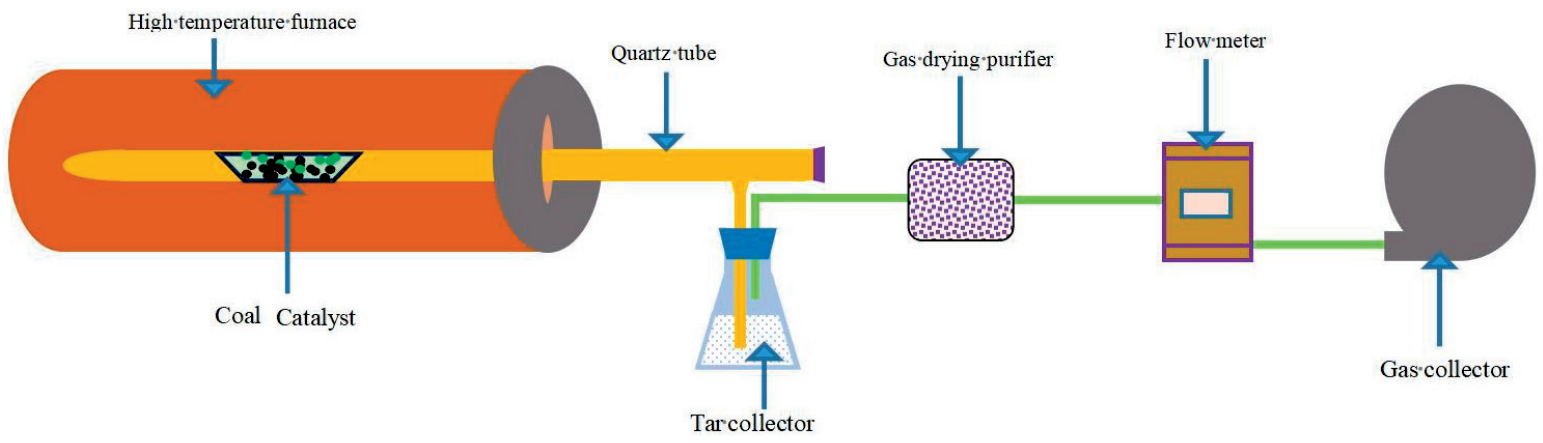

Fig. 1. Reaction device diagram.

\section{Results and Discussion} Effect of Subgroup Metal Oxide Supported $\gamma-\mathrm{Al}_{2} \mathrm{O}_{3}$
Catalyst on Coal Pyrolysis Products

\section{Effect of Subgroup Metal Oxide Supported $\gamma-\mathrm{Al}_{2} \mathrm{O}_{3}$ Catalyst on Gas and Tar}

Fig. 2 showed the changes of gas products and tar under the conditions of final pyrolysis temperature $600^{\circ} \mathrm{C}$ and constant temperature of $5 \mathrm{~min}$ after mixing $15 \mathrm{~g}$ coal and $\mathrm{g}$ subgroup metal oxide supported $\gamma-\mathrm{Al}_{2} \mathrm{O}_{3}$ catalyst into pyrolysis furnace. As can be seen from Fig. 2, the tar yield and gas yield of raw coal pyrolysis were $0.75 \mathrm{~g}$ and $1.58 \mathrm{~g}$ respectively; and the tar and gas contents were improved by adding $\gamma-\mathrm{Al}_{2} \mathrm{O}_{3}$, $\mathrm{Fe}_{2} \mathrm{O}_{3} / \gamma-\mathrm{Al}_{2} \mathrm{O}_{3}, \mathrm{CoO} / \gamma-\mathrm{Al}_{2} \mathrm{O}_{3}$ and $\mathrm{NiO} / \gamma-\mathrm{Al}_{2} \mathrm{O}_{3}$ in the process of coal pyrolysis $\mathrm{Fe}_{2} \mathrm{O}_{3} / \gamma-\mathrm{Al}_{2} \mathrm{O}_{3}$ resulted in the highest tar yield of $0.75 \mathrm{~g}$, which was $134.38 \%$ higher than that of raw coal; while $\mathrm{CoO} / \gamma-\mathrm{Al}_{2} \mathrm{O}_{3}$ resulted in the highest gas yield of $1.65 \mathrm{~g}$, which was $4.4 \%$ higher than that of raw coal. When coal and $\gamma-\mathrm{Al}_{2} \mathrm{O}_{3}$ were pyrolyzed together, the contact between coal and $\gamma-\mathrm{Al}_{2} \mathrm{O}_{3}$ resulted in the breaking of macromolecular chains in coal, which promoted the pyrolysis of coal and produced more pyrolytic products. The pyrolysis products entered into $\gamma-\mathrm{Al}_{2} \mathrm{O}_{3}$ and came into contact with the active sites, which further lead to the breaking of macromolecules and the vaporization and volatilization of small molecules at higher temperatures, thus increasing tar yield. When $\gamma-\mathrm{Al}_{2} \mathrm{O}_{3}$ was loaded with $\mathrm{Fe}_{2} \mathrm{O}_{3}, \mathrm{Co}_{2} \mathrm{O}_{3}$ and $\mathrm{Ni}_{2} \mathrm{O}_{3}$, the active sites were increased on the surface and in the interior of $\gamma-\mathrm{Al}_{2} \mathrm{O}_{3}$, which promoted the cracking of macromolecular substances and further increased the yield of tar and gas. $\mathrm{Fe}_{2} \mathrm{O}_{3}, \mathrm{Co}_{2} \mathrm{O}_{3}$ and $\mathrm{Ni}_{2} \mathrm{O}_{3}$ were used as the active components, of which $\mathrm{Fe}_{2} \mathrm{O}_{3}$ was the most active.

\section{Effect of Subgroup Metal Oxide Supported $\gamma-\mathrm{Al}_{2} \mathrm{O}_{3}$ Catalyst on Gas Components}

Fig. 3 showed the mixture of $15 \mathrm{~g}$ coal sample and $3 \mathrm{~g}$ catalyst and pyrolysis in the pyrolysis furnace. Figs 3(a-e) arespectively represented the raw coal, adding $\gamma-\mathrm{Al}_{2} \mathrm{O}_{3}$ catalyst, $\mathrm{Fe}_{2} \mathrm{O}_{3} / \gamma-\mathrm{Al}_{2} \mathrm{O}_{3}$ catalyst, $\mathrm{Co}_{2} \mathrm{O}_{3} /$ $\gamma-\mathrm{Al}_{2} \mathrm{O}_{3}$ catalyst and $\mathrm{NiO} / \gamma-\mathrm{Al}_{2} \mathrm{O}_{3}$ catalyst, and the gas composition changed with the pyrolysis temperature. As can be seen from Fig. 3, the variation trend of gas with pyrolysis temperature was basically the same after the addition of different catalysts. $\mathrm{CH}_{4}$ content reach the maximum when the pyrolysis temperature reaches $500^{\circ} \mathrm{C}$ to $550^{\circ} \mathrm{C}$. When the pyrolysis temperature reach

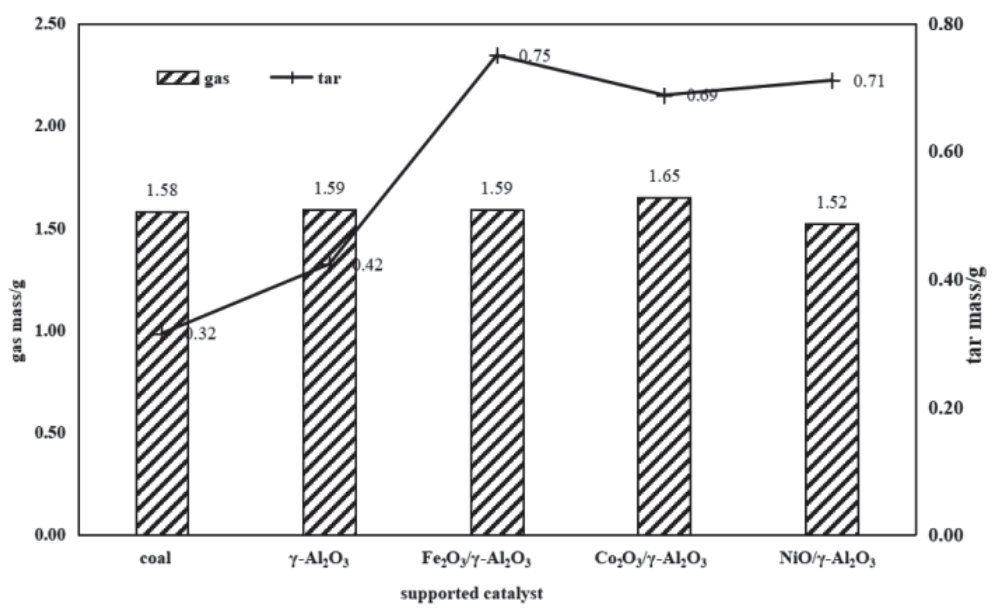

Fig. 2. Effect of subgroup metal oxide supported $\gamma-\mathrm{Al}_{2} \mathrm{O}_{3}$ catalyst on gas and tar. 

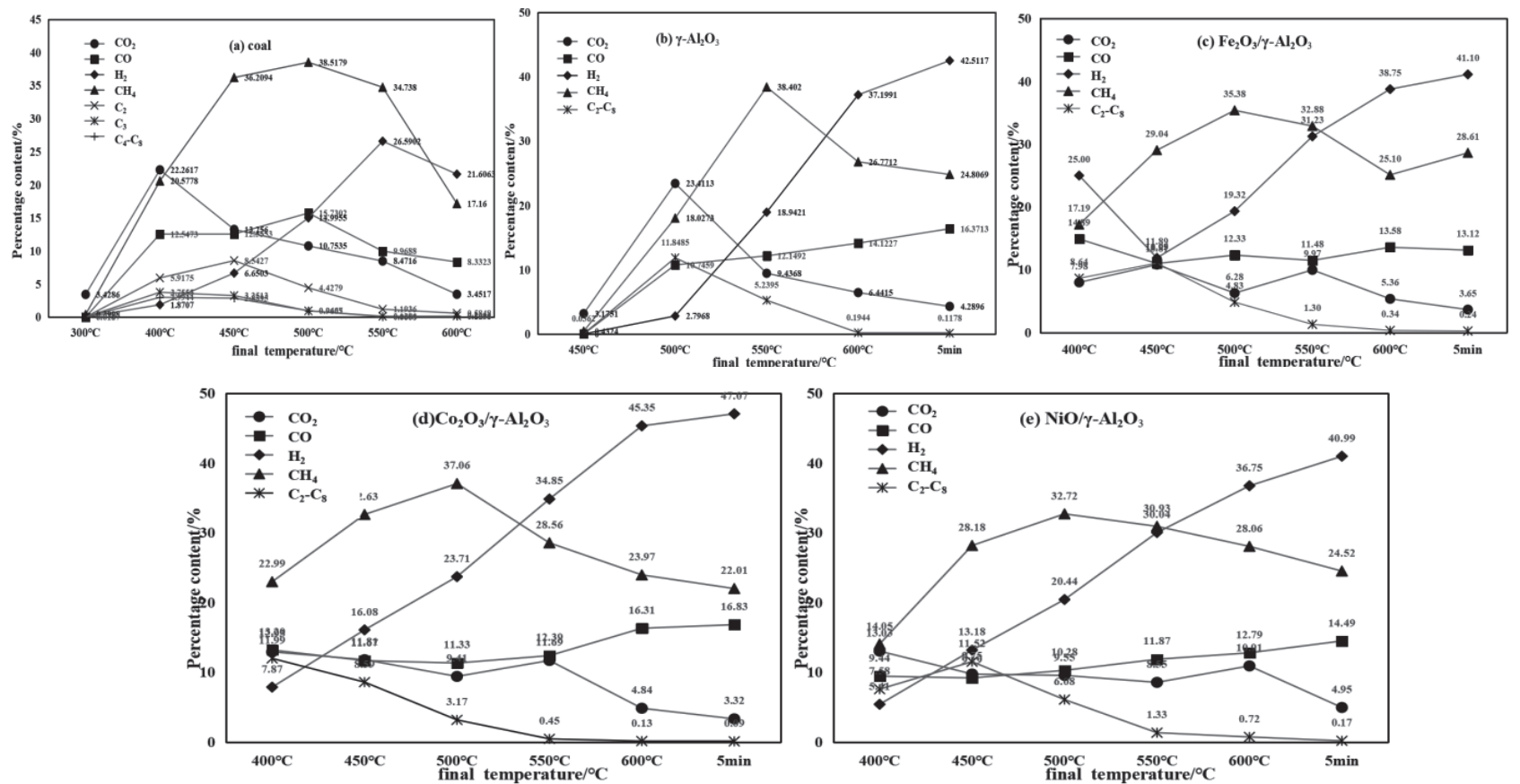

Fig. 3. The effect of subgroup metal oxide supported $\gamma-\mathrm{Al}_{2} \mathrm{O}_{3}$ catalyst on coal pyrolysis gas composition a) coal, b) $\left.\gamma-\mathrm{Al}_{2} \mathrm{O}_{3}, \mathrm{c}\right) \mathrm{Fe}_{2} \mathrm{O}_{3} / \gamma$ $\left.\left.\mathrm{Al}_{2} \mathrm{O}_{3}, \mathrm{~d}\right) \mathrm{Co}_{2} \mathrm{O}_{3} / \gamma-\mathrm{Al}_{2} \mathrm{O}_{3}, \mathrm{e}\right) \mathrm{NiO} / \gamma-\mathrm{Al}_{2} \mathrm{O}_{3}$.

$600^{\circ} \mathrm{C}$ and the final temperature was $600^{\circ} \mathrm{C}$ and kept for $5 \mathrm{~min}$, the $\mathrm{H}_{2}$ content reach the maximum, and the $\mathrm{CO}$ content reach the maximum when the final temperature was $600^{\circ} \mathrm{C}$ and kept for $5 \mathrm{~min}$. Coal pyrolysis can be roughly divided into three stages [18]. The first stage was from room temperature to $350^{\circ} \mathrm{C}$, which was dry and degassing, mainly due to physical changes. The second stage was $350^{\circ} \mathrm{C}$ to $550^{\circ} \mathrm{C}$, mainly depolymerization and decomposition, a large number of volatile gas and tar was also the process of coal bonding into coke. The third stage was $550^{\circ} \mathrm{C}$ to $1000^{\circ} \mathrm{C}$, the secondary degassing was mainly condensation polymerization, the tar was less, the volatiles were mainly hydrocarbon gases, hydrogen and carbon oxides. The maximum total contents of $\mathrm{CO}, \mathrm{H}_{2}$ and $\mathrm{CH}_{4}$ produced by pyrolysis of raw coal, $\gamma-\mathrm{Al}_{2} \mathrm{O}_{3}, \quad \mathrm{Fe}_{2} \mathrm{O}_{3} / \gamma-\mathrm{Al}_{2} \mathrm{O}_{3}$ catalyst, $\mathrm{Co}_{2} \mathrm{O}_{3} / \gamma-$ $\mathrm{Al}_{2} \mathrm{O}_{3}$ catalyst and $\mathrm{NiO} / \gamma-\mathrm{Al}_{2} \mathrm{O}_{3}$ catalyst were $71.40 \%$, $83.69 \%, 82.83 \%, 85.91 \%$ and $80.00 \%$, respectively. The corresponding pyrolysis conditions were $550^{\circ} \mathrm{C}, 600^{\circ} \mathrm{C}$ for $5 \mathrm{~min}, 600^{\circ} \mathrm{C}$ for $5 \mathrm{~min}, 600^{\circ} \mathrm{C}$ for $5 \mathrm{~min}, 600^{\circ} \mathrm{C}$ for $5 \mathrm{~min}$ and $600^{\circ} \mathrm{C}$ for $5 \mathrm{~min}$. According to the above analysis, $\mathrm{Co}_{2} \mathrm{O}_{3} / \gamma-\mathrm{Al}_{2} \mathrm{O}_{3}$ catalyst had a better effect on the catalytic pyrolysis of coal to produce hydrogen-rich fuel gas.

\section{Effect of Group VIII Metal Oxide Supported $\gamma-\mathrm{Al}_{2} \mathrm{O}_{3}$ Catalyst on Coal Pyrolysis Products}

\section{Effect of Group VIII Metal Oxide Supported $\gamma-\mathrm{Al}_{2} \mathrm{O}_{3}$ Catalyst on Gas, Oil and Loss}

Fig. 4 was the change of gas product and tar by putting $15 \mathrm{~g}$ coal sample and $3 \mathrm{~g}$ group VIII metal oxide supported $\gamma-\mathrm{Al}_{2} \mathrm{O}_{3}$ catalyst into the pyrolysis furnace at the final temperature of $600^{\circ} \mathrm{C}$ and constant temperature of $5 \mathrm{~min}$. It can be seen from Fig. 4 that the liquid and gas contents were increased by adding $\mathrm{CuO} / \gamma-\mathrm{Al}_{2} \mathrm{O}_{3}, \quad \mathrm{ZnO} / \gamma-\mathrm{Al}_{2} \mathrm{O}_{3}, \quad \mathrm{Mo}_{2} \mathrm{O}_{3} / \gamma-\mathrm{Al}_{2} \mathrm{O}_{3}, \quad \mathrm{Cr}_{2} \mathrm{O}_{3} / \gamma-$ $\mathrm{Al}_{2} \mathrm{O}_{3}$ and $\mathrm{Mn}_{2} \mathrm{O}_{3} / \gamma-\mathrm{Al}_{2} \mathrm{O}_{3}$ during coal pyrolysis, and $\mathrm{Cr}_{2} \mathrm{O}_{3} / \gamma-\mathrm{Al}_{2} \mathrm{O}_{3}$ resulted in the highest tar yield of $0.71 \mathrm{~g}$, which was $121.88 \%$ higher than that of raw coal The gas production was also the highest, at $1.73 \mathrm{~g}$, which was $9.5 \%$ higher than that of raw coal. When coal and $\mathrm{Cr}_{2} \mathrm{O}_{3} / \gamma-\mathrm{Al}_{2} \mathrm{O}_{3}$ were pyrolyzed together, the contact between coal and active sites on $\mathrm{Cr}_{2} \mathrm{O}_{3} / \gamma-\mathrm{Al}_{2} \mathrm{O}_{3}$ surface resulted in the breaking of macromolecular chains in coal, which promoted the pyrolysis of coal and produced more pyrolytic products. The pyrolytic products came into contact with active $\mathrm{Cr}_{2} \mathrm{O}_{3}$ inside $\mathrm{Cr}_{2} \mathrm{O}_{3} / \gamma-\mathrm{Al}_{2} \mathrm{O}_{3}$, and further caused the breaking of macromolecules to produce small molecules, which were easy to vaporize and volatilize at higher temperature, therefore, $\mathrm{Cr}_{2} \mathrm{O}_{3} / \gamma$ $\mathrm{Al}_{2} \mathrm{O}_{3}$ made the total amount of tar and gas produced in the mixed pyrolysis process the highest, and the catalytic effect was the best.

\section{Effect of Group VIII Metal Oxide Supported $\gamma-\mathrm{Al}_{2} \mathrm{O}_{3}$ Catalyst on Gas Components}

Fig. 5(a-e) respectively represented adding $\mathrm{CuO} / \gamma$ $\mathrm{Al}_{2} \mathrm{O}_{3}$ catalyst, $\mathrm{ZnO} / \gamma-\mathrm{Al}_{2} \mathrm{O}_{3}$ catalyst, $\mathrm{Mo}_{2} \mathrm{O}_{3} / \gamma-\mathrm{Al}_{2} \mathrm{O}_{3}$ catalyst, $\mathrm{Cr}_{2} \mathrm{O}_{3} / \gamma-\mathrm{Al}_{2} \mathrm{O}_{3}$ catalyst and $\mathrm{Mn}_{2} \mathrm{O}_{3} / \gamma-\mathrm{Al}_{2} \mathrm{O}_{3}$ catalyst, and the gas composition changed with the pyrolysis temperature. In Fig. 5, it can be seen that the change trend of gas with pyrolysis temperature was basically the same after adding different catalysts, and 


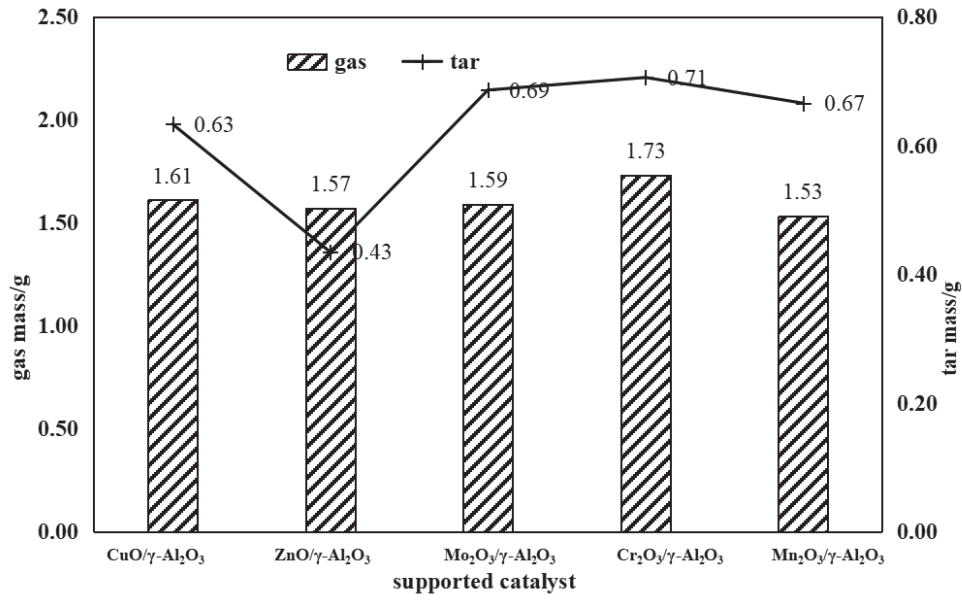

Fig. 4. Effect of group VIII metal oxide supported $\gamma-\mathrm{Al}_{2} \mathrm{O}_{3}$ catalyst on gas and tar.

the content of $\mathrm{CH}_{4}$ reached the maximum when the pyrolysis temperature reached $500^{\circ} \mathrm{C}$ to $550^{\circ} \mathrm{C}$. When the pyrolysis temperature reached $600^{\circ} \mathrm{C}$ and the final temperature reached $600^{\circ} \mathrm{C}$ for $5 \mathrm{~min}$, the content of $\mathrm{H}_{2}$ was the maximum. And the content of $\mathrm{CO}$ reached the maximum at the final temperature of $600^{\circ} \mathrm{C}$ for 5 min. The maximum total contents of $\mathrm{CO}, \mathrm{H}_{2}$ and $\mathrm{CH}_{4}$ produced by pyrolysis of $\mathrm{CuO} / \gamma-\mathrm{Al}_{2} \mathrm{O}_{3}$ catalyst, $\mathrm{ZnO} / \gamma-\mathrm{Al}_{2} \mathrm{O}_{3}$ catalyst, $\mathrm{Mo}_{2} \mathrm{O}_{3} / \gamma-\mathrm{Al}_{2} \mathrm{O}_{3}$ catalyst, $\mathrm{Cr}_{2} \mathrm{O}_{3} / \gamma-$ $\mathrm{Al}_{2} \mathrm{O}_{3}$ catalyst and $\mathrm{Mn}_{2} \mathrm{O}_{3} / \gamma-\mathrm{Al}_{2} \mathrm{O}_{3}$ catalyst were $79.62 \%$, $80.66 \%, 79.96 \%, 87.31 \%$ and $74.95 \%$, respectively. The corresponding pyrolysis conditions were $600^{\circ} \mathrm{C}$ for $5 \mathrm{~min}, 600^{\circ} \mathrm{C}$ for $5 \mathrm{~min}, 600^{\circ} \mathrm{C}$ for $5 \mathrm{~min}, 600^{\circ} \mathrm{C}$ for $5 \mathrm{~min}$ and $550^{\circ} \mathrm{C}$. According to the above analysis, $\mathrm{Cr}_{2} \mathrm{O}_{3} / \gamma-\mathrm{Al}_{2} \mathrm{O}_{3}$ catalyst had a better effect on the catalytic pyrolysis of coal to produce hydrogen-rich fuel gas.

\section{Effect of Different Loading $\mathrm{Cr}_{2} \mathrm{O}_{3} / \gamma-\mathrm{Al}_{2} \mathrm{O}_{3}$ Catalyst on Coal Pyrolysis Products}

\section{Effect of Different Loading $\mathrm{Cr}_{2} \mathrm{O}_{3} / \gamma-\mathrm{Al}_{2} \mathrm{O}_{3}$ Catalyst on Gas and Tar}

Fig. 6 shows the change of gas product and tar by putting $15 \mathrm{~g}$ coal sample and $3 \mathrm{~g} \mathrm{Cr}_{2} \mathrm{O}_{3} / \gamma-\mathrm{Al}_{2} \mathrm{O}_{3}$ catalyst with loading of $1 \%, 5 \%$ and $11 \%$ into the pyrolysis furnace at the final temperature of $600^{\circ} \mathrm{C}$ and constant temperature of $5 \mathrm{~min}$. As can be seen from Fig. 6, the liquid and gas contents increased with the addition of
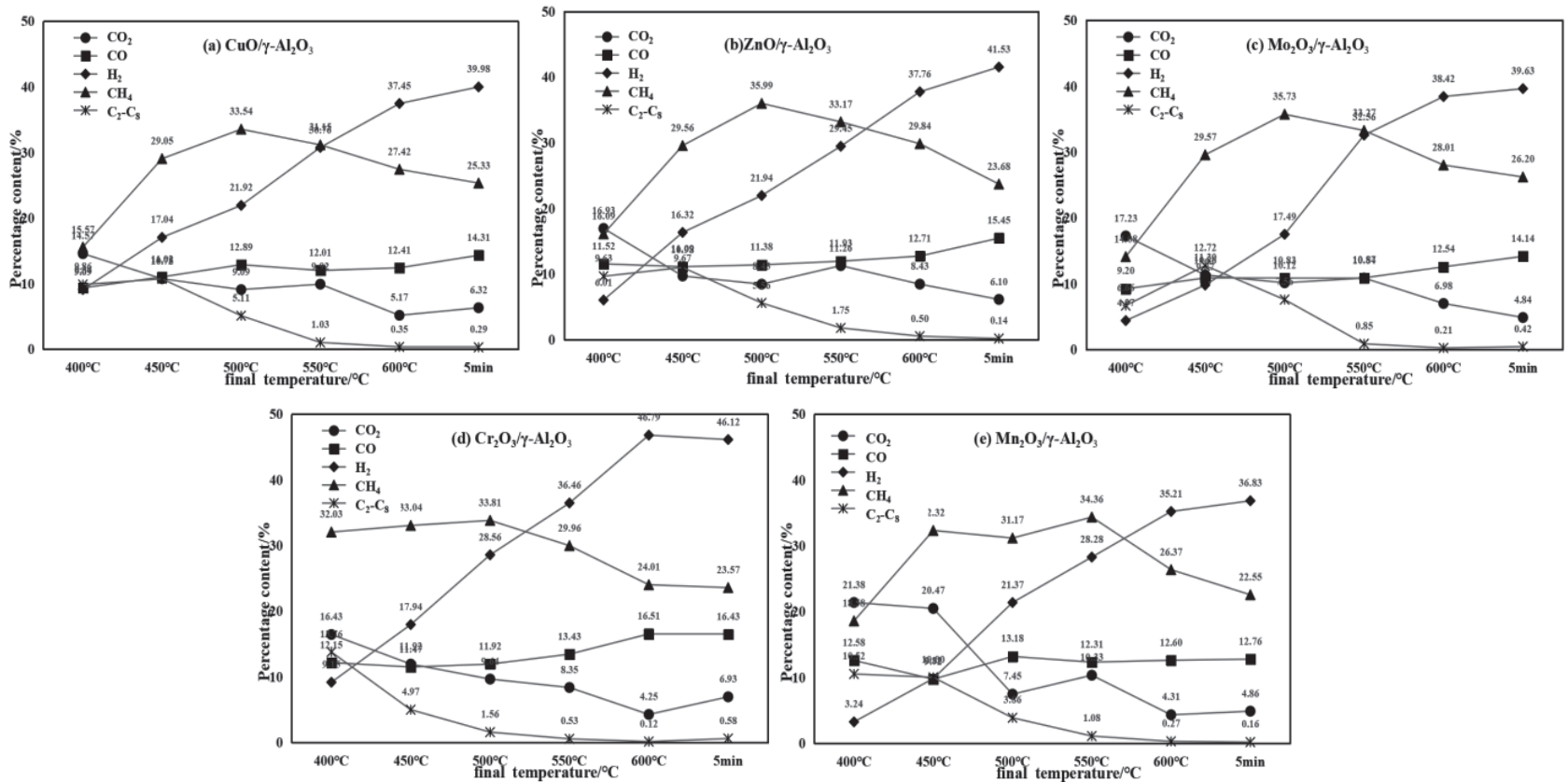

Fig. 5. Effect of group VIII metal oxide supported $\gamma-\mathrm{Al}_{2} \mathrm{O}_{3}$ catalyst on gas components a) $\left.\left.\mathrm{CuO} / \gamma-\mathrm{Al}_{2} \mathrm{O}_{3}, \mathrm{~b}\right) \mathrm{ZnO} / \gamma-\mathrm{Al}_{2} \mathrm{O}_{3}, \mathrm{c}\right) \mathrm{Mo}_{2} \mathrm{O}_{3} / \gamma-$ $\mathrm{Al}_{2} \mathrm{O}_{3}$, d) $\mathrm{Cr}_{2} \mathrm{O}_{3} / \gamma-\mathrm{Al}_{2} \mathrm{O}_{3}$, e) $\mathrm{Mn}_{2} \mathrm{O}_{3} / \gamma-\mathrm{Al}_{2} \mathrm{O}_{3}$. 


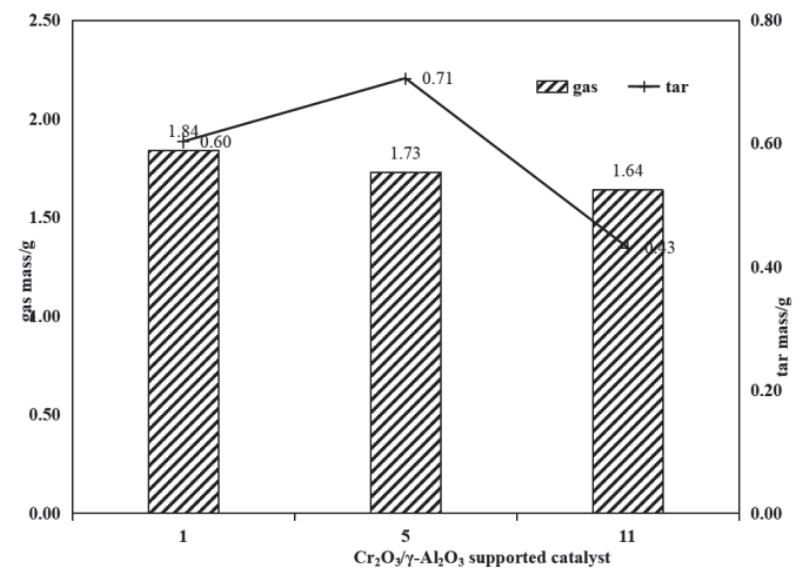

Fig. 6. Effect of $\mathrm{Cr}_{2} \mathrm{O}_{3} / \gamma-\mathrm{Al}_{2} \mathrm{O}_{3}$ catalysts with different loading loads on gas and tar.

$\mathrm{Cr}_{2} \mathrm{O}_{3} / \gamma-\mathrm{Al}_{2} \mathrm{O}_{3}$ catalysts with different loading during coal pyrolysis, but the liquid and gas contents decreased with the increase of loading. A large amount of active components were produced in $\gamma-\mathrm{Al}_{2} \mathrm{O}_{3}$ carrier after calcination, which greatly improved the activity of the catalyst. However, the active components can easily block the internal channels of the carrier, thus reducing the specific surface area and pore diameter, and thus reducing the number of tar molecules entering the catalyst, this further reduced tar production and gas production. So when the load was $1 \%$, the liquid and gas production was the largest.

\section{Effect of Different Loading $\mathrm{Cr}_{2} \mathrm{O}_{3} / \gamma-\mathrm{Al}_{2} \mathrm{O}_{3}$ Catalyst on Gas Components}

Fig. 7 shows that $15 \mathrm{~g}$ coal sample and $3 \mathrm{~g}$ $\mathrm{Cr}_{2} \mathrm{O}_{3} / \gamma-\mathrm{Al}_{2} \mathrm{O}_{3}$ catalyst with $1 \%, 5 \%$ and $11 \%$ loading was mixed evenly and pyrolyzed in a pyrolyzer, and the gas composition changed with the pyrolysis temperature. In Fig. 7, it can be seen that the change trend of gas with pyrolysis temperature was basically the same. The content of $\mathrm{CH}_{4}$ reached the maximum when the pyrolysis temperature reached $500^{\circ} \mathrm{C}$. The content of $\mathrm{H}_{2}$ reached the maximum when the pyrolysis temperature reached $600^{\circ} \mathrm{C}$ and $600^{\circ} \mathrm{C}$ for $5 \mathrm{~min}$. The content of $\mathrm{CO}$ reached the maximum when the final temperature was $600^{\circ} \mathrm{C}$ and constant temperature was 5 min. The highest total contents of $\mathrm{CO}, \mathrm{H}_{2}$ and $\mathrm{CH}_{4}$ were $88.48 \%, 87.31 \%$ and $80.42 \%$ respectively when $\mathrm{Cr}_{2} \mathrm{O}_{3} / \gamma-\mathrm{Al}_{2} \mathrm{O}_{3}$ catalysts with $1 \%, 5 \%$ and $11 \%$ loading were pyrolyzed. The corresponding pyrolytic conditions were all $600^{\circ} \mathrm{C}$. Based on the above analysis, the effect of $\mathrm{Cr}_{2} \mathrm{O}_{3} / \gamma-\mathrm{Al}_{2} \mathrm{O}_{3}$ catalyst on the preparation of hydrogen-rich fuel gas was better than that of $\mathrm{Cr}_{2} \mathrm{O}_{3} / \gamma-$ $\mathrm{Al}_{2} \mathrm{O}_{3}$ catalyst with $1 \%$ loading. According to the above analysis, when the catalyst load was $1 \%, \mathrm{Cr}_{2} \mathrm{O}_{3} / \gamma-\mathrm{Al}_{2} \mathrm{O}$ catalyst had a better effect on the catalytic pyrolysis of coal to produce hydrogen-rich fuel gas.

\section{Characterization}

\section{BET}

Table 3 showed the specific surface area of different $\gamma-\mathrm{Al}_{2} \mathrm{O}_{3}$ catalysts. In the process of coal pyrolysis, oil vapor molecules from coal entered the catalyst and contacted with the active site to produce small molecular substances, the specific surface area and pore size of catalysts played an important role in catalytic cracking of oil vapor molecules. It can be seen from Table 3 that the specific surface area of $\gamma-\mathrm{Al}_{2} \mathrm{O}_{3}$ is $271.64 \mathrm{~m}^{2} / \mathrm{g}$, and the specific surface areas of $\mathrm{Fe}_{2} \mathrm{O}_{3} / \gamma$ $\mathrm{Al}_{2} \mathrm{O}_{3}, \quad \mathrm{Co}_{2} \mathrm{O}_{3} / \gamma-\mathrm{Al}_{2} \mathrm{O}_{3}, \quad \mathrm{Ni}_{2} \mathrm{O}_{3} / \gamma-\mathrm{Al}_{2} \mathrm{O}_{3}, \quad \mathrm{CuO} / \gamma-\mathrm{Al}_{2} \mathrm{O}_{3}$, $\mathrm{ZnO} / \gamma-\mathrm{Al}_{2} \mathrm{O}_{3}, \quad \mathrm{Mo}_{2} \mathrm{O}_{3} / \gamma-\mathrm{Al}_{2} \mathrm{O}_{3}, \quad \mathrm{Cr}_{2} \mathrm{O}_{3} / \gamma-\mathrm{Al}_{2} \mathrm{O}_{3} \quad$ and $\mathrm{Mn}_{2} \mathrm{O}_{3} / \gamma-\mathrm{Al}_{2} \mathrm{O}_{3}$ decreased after loading, the reason was that the catalyst after being loaded was calcined to form oxide, which cloged the pore channels of the support and lead to a small specific surface area. However, $\gamma$ $\mathrm{Al}_{2} \mathrm{O}_{3}$ and $\mathrm{Cr}_{2} \mathrm{O}_{3} / \gamma-\mathrm{Al}_{2} \mathrm{O}_{3}$ had better catalytic cracking effect on coal pyrolysis, which was due to their large specific surface area, better adsorption of oil and gas molecules and contacted with active sites.
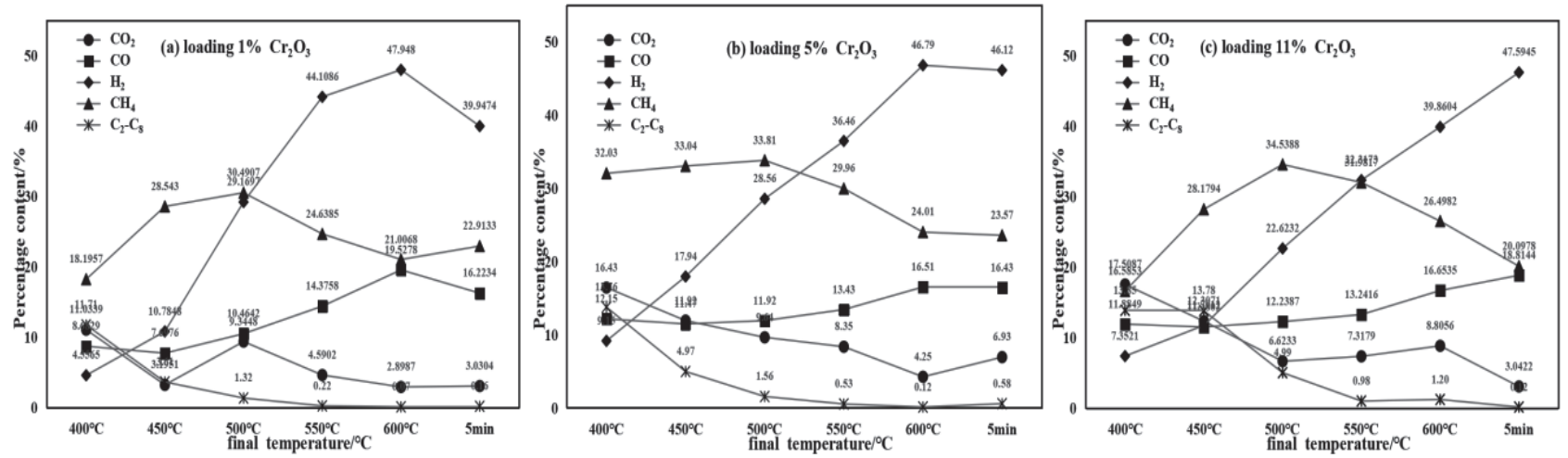

Fig. 7. Effect of different loading $\mathrm{Cr}_{2} \mathrm{O}_{3} / \gamma-\mathrm{Al}_{2} \mathrm{O}_{3}$ on gas components a) loading $1 \% \mathrm{Cr}_{2} \mathrm{O}_{3} / \gamma-\mathrm{Al}_{2} \mathrm{O}_{3}$, b) loading $5 \% \mathrm{Cr}_{2} \mathrm{O}_{3} / \gamma-\mathrm{Al}_{2} \mathrm{O}_{3}$, c) loading $11 \% \mathrm{Cr}_{2} \mathrm{O}_{3} / \gamma-\mathrm{Al}_{2} \mathrm{O}_{3}$. 
Table 3. specific surface area of $\gamma-\mathrm{Al}_{2} \mathrm{O}_{3}$ catalyst $\left(\mathrm{m}^{2} / \mathrm{g}\right)$.

\begin{tabular}{|c|c|c|c|}
\hline Catalyst & Specific surface area & Catalyst & Specific surface area \\
\hline$\gamma-\mathrm{Al}_{2} \mathrm{O}_{3}$ & 271.64 & $\mathrm{CuO} / \gamma-\mathrm{Al}_{2} \mathrm{O}_{3}$ & 200.34 \\
\hline $\mathrm{Fe}_{2} \mathrm{O}_{3} / \gamma-\mathrm{Al}_{2} \mathrm{O}_{3}$ & 251.88 & $\mathrm{ZnO} / \gamma-\mathrm{Al}_{2} \mathrm{O}_{3}$ & 203.12 \\
\hline $\mathrm{Co}_{2} \mathrm{O}_{3} / \gamma-\mathrm{Al}_{2} \mathrm{O}_{3}$ & 249.67 & $\mathrm{Mo}_{2} \mathrm{O}_{3} / \gamma-\mathrm{Al}_{2} \mathrm{O}_{3}$ & 247.99 \\
\hline $\mathrm{Ni}_{2} \mathrm{O}_{3} / \gamma-\mathrm{Al}_{2} \mathrm{O}_{3}$ & 250.20 & $\mathrm{Cr}_{2} \mathrm{O}_{3} / \gamma-\mathrm{Al}_{2} \mathrm{O}_{3}$ & 258.43 \\
\hline & & $\mathrm{Mn}_{2} \mathrm{O}_{3} / \gamma-\mathrm{Al}_{2} \mathrm{O}_{3}$ & 245.77 \\
\hline
\end{tabular}

\section{$\mathrm{XRD}$}

Fig. 8 showed the XRD patterns of $\mathrm{Fe}_{2} \mathrm{O}_{3} / \gamma-\mathrm{Al}_{2} \mathrm{O}_{3}$, $\mathrm{Co}_{2} \mathrm{O}_{3} / \gamma-\mathrm{Al}_{2} \mathrm{O}_{3}, \quad \mathrm{Ni}_{2} \mathrm{O}_{3} / \gamma-\mathrm{Al}_{2} \mathrm{O}_{3}, \quad \mathrm{CuO} / \gamma-\mathrm{Al}_{2} \mathrm{O}_{3}, \quad \mathrm{ZnO} / \gamma-$ $\mathrm{Al}_{2} \mathrm{O}_{3}, \quad \mathrm{Mo}_{2} \mathrm{O}_{3} / \gamma-\mathrm{Al}_{2} \mathrm{O}_{3}, \quad \mathrm{Cr}_{2} \mathrm{O}_{3} / \gamma-\mathrm{Al}_{2} \mathrm{O}_{3}$ and $\mathrm{Mn}_{2} \mathrm{O}_{3} / \gamma-$ $\mathrm{Al}_{2} \mathrm{O}_{3}$. As can be seen from Fig. 8, the impregnated $\gamma-\mathrm{Al}_{2} \mathrm{O}_{3}$ formed corresponding metal oxides on the catalyst after roasting in a muffle furnace. In Fig. 8(1), the $2 \theta$ angles of $32.78^{\circ}, 36.54^{\circ}, 37.51^{\circ}, 43.17^{\circ}, 45.79^{\circ}$, $66.76^{\circ}$ and $67.31^{\circ}$ were the characteristic peaks of $\gamma-\mathrm{Al}_{2} \mathrm{O}_{3}$ [19]. In Fig. 8(2), the $2 \theta$ angles $36.04^{\circ}, 41.92^{\circ}$, $60.69^{\circ}$ and $61.25^{\circ}$ were the characteristic peaks of $\mathrm{FeO}$, and the $2 \theta$ angles $14.73^{\circ}, 24.71^{\circ}, 31.13^{\circ}, 32.98^{\circ}$, $35.68^{\circ}, 38.10^{\circ}, 47.30^{\circ}, 54.90^{\circ}, 67.10^{\circ}$ and $70.18^{\circ}$ were the characteristic peaks of $\mathrm{Fe}_{2} \mathrm{O}_{3}$ [20]. In Fig. 8(3), $2 \theta$ angles $34.15^{\circ}, 36.49^{\circ}, 42.39^{\circ}, 57.30^{\circ}$ and $61.52^{\circ}$ were characteristic peaks of $\mathrm{CoO} ; 2 \theta$ angles $31.27^{\circ}, 36.85^{\circ}$, $44.80^{\circ}, 59.35^{\circ}$ and $65.23^{\circ}$ were characteristic peaks of $\mathrm{Co}_{3} \mathrm{O}_{4} ; 2 \theta$ angles $27.77^{\circ}, 31.14^{\circ}, 38.61^{\circ}, 51.28^{\circ}$, $56.40^{\circ}, 58.76^{\circ}$ and $67.31^{\circ}$ were characteristic peaks of $\mathrm{Co}_{2} \mathrm{O}_{3}$ [21]. In Fig. 8(4), $2 \theta$ angles $37.25^{\circ}$ and $43.29^{\circ}$ were the characteristic peaks of $\mathrm{NiO}, 2 \theta$ angles $31.94^{\circ}$, $39.13^{\circ}, 44.83^{\circ}, 51.59^{\circ}, 56.78^{\circ}, 66.71^{\circ}$ and $87.89^{\circ}$ were the characteristic peaks of $\mathrm{Ni}_{2} \mathrm{O}_{3}$ [22]. In Fig. 8(5), $2 \theta$ angles $32.50^{\circ}, 35.50^{\circ}, 38.47^{\circ}, 48.59^{\circ}, 61.34^{\circ}$ and $67.85^{\circ}$ were characteristic peaks of $\mathrm{CuO}$, and $2 \theta$ angles $37.01^{\circ}$,
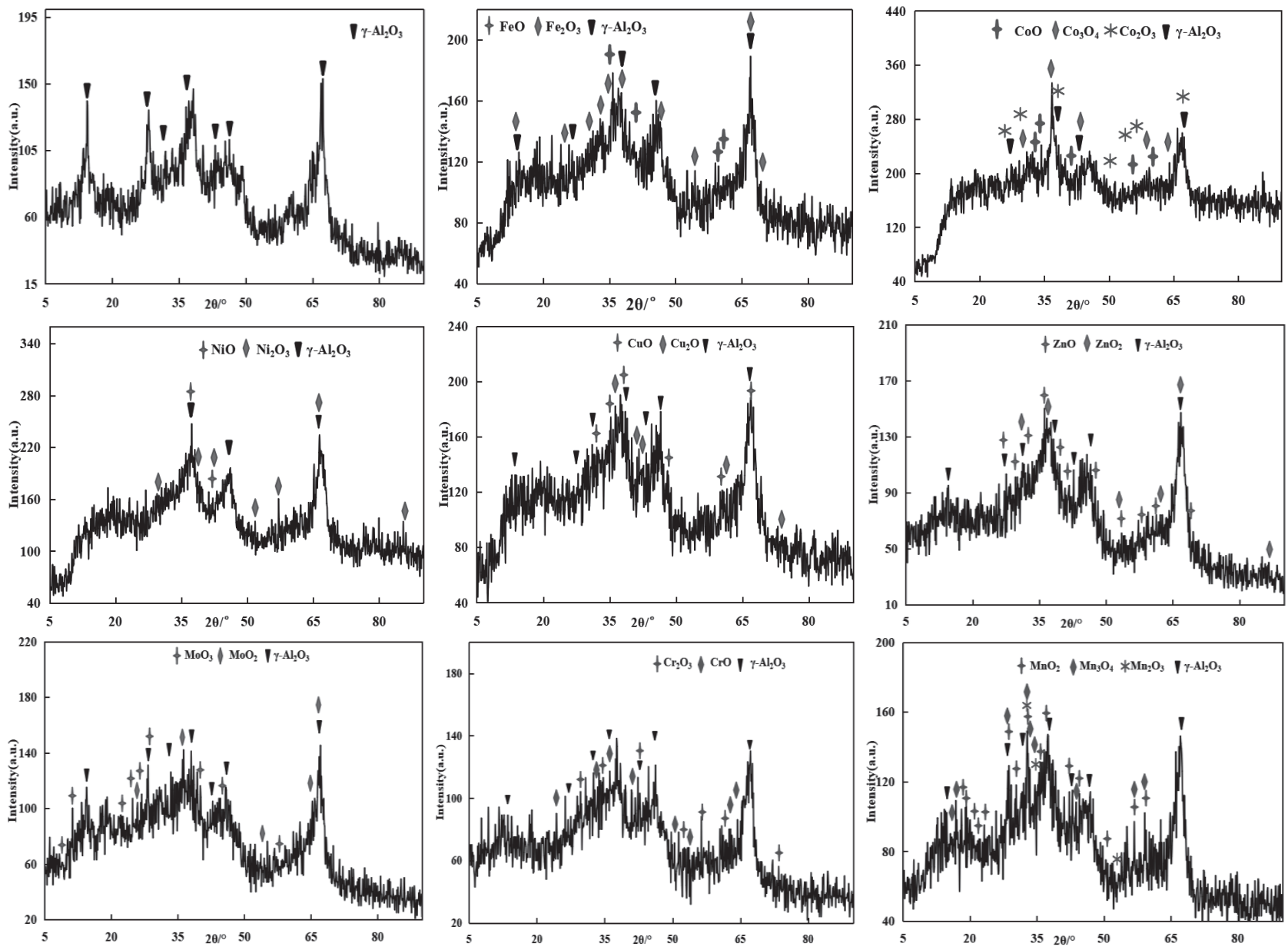

Fig. 8. XRD of $\gamma-\mathrm{Al}_{2} \mathrm{O}_{3}$ catalyst (1) $\gamma-\mathrm{Al}_{2} \mathrm{O}_{3}$, (2) $\mathrm{Fe}_{2} \mathrm{O}_{3} / \gamma-\mathrm{Al}_{2} \mathrm{O}_{3}$, (3) $\mathrm{Co}_{2} \mathrm{O}_{3} / \gamma-\mathrm{Al}_{2} \mathrm{O}_{3}$, (4) $\mathrm{NiO} / \gamma-\mathrm{Al}_{2} \mathrm{O}_{3},(5) \mathrm{CuO} / \gamma-\mathrm{Al}_{2} \mathrm{O}_{3}$., (6) $\mathrm{ZnO} / \gamma-\mathrm{Al}_{2} \mathrm{O}_{3}$, (7) $\mathrm{Mo}_{2} \mathrm{O}_{3} / \gamma-\mathrm{Al}_{2} \mathrm{O}_{3},(8) \mathrm{Cr}_{2} \mathrm{O}_{3} / \gamma-\mathrm{Al}_{2} \mathrm{O}_{3}$, (9) $\mathrm{NiO} / \gamma-\mathrm{Al}_{2} \mathrm{O}_{3}$. 
Table 4. Metal element determination results of supported $\gamma-\mathrm{Al}_{2} \mathrm{O}_{3}$ catalyst (\%).

\begin{tabular}{|c|c|c|c|c|}
\hline Catalyst & Elements & Theoretical value & Determination of value & Load factor \\
\hline $\mathrm{Fe}_{2} \mathrm{O}_{3} / \gamma-\mathrm{Al}_{2} \mathrm{O}_{3}$ & $\mathrm{Fe}$ & 3.50 & 3.01 & 86.00 \\
\hline $\mathrm{Co}_{2} \mathrm{O}_{3} / \gamma-\mathrm{Al}_{2} \mathrm{O}_{3}$ & $\mathrm{Co}$ & 3.55 & 3.05 & 85.92 \\
\hline $\mathrm{Ni}_{2} \mathrm{O}_{3} / \gamma-\mathrm{Al}_{2} \mathrm{O}_{3}$ & $\mathrm{Ni}$ & 3.08 & 86.03 \\
\hline $\mathrm{CuO} / \gamma-\mathrm{Al}_{2} \mathrm{O}_{3}$ & $\mathrm{Cu}$ & 3.58 & 3.40 & 85.00 \\
\hline $\mathrm{ZnO} / \gamma-\mathrm{Al}_{2} \mathrm{O}_{3}$ & $\mathrm{Zn}$ & 4.00 & 3.47 & 86.53 \\
\hline $\mathrm{Mo}_{2} \mathrm{O}_{3} / \gamma-\mathrm{Al}_{2} \mathrm{O}_{3}$ & $\mathrm{Mo}$ & 6.67 & 5.72 & 85.76 \\
\hline $\mathrm{Cr}_{2} \mathrm{O}_{3} / \gamma-\mathrm{Al}_{2} \mathrm{O}_{3}$ & $\mathrm{Cr}$ & 3.42 & 3.00 & 87.72 \\
\hline $\mathrm{Mn}_{2} \mathrm{O}_{3} / \gamma-\mathrm{Al}_{2} \mathrm{O}_{3}$ & $\mathrm{Mn}$ & 3.48 & 3.01 & 86.49 \\
\hline
\end{tabular}

$40.64^{\circ}, 42.61^{\circ}, 62.44^{\circ}$ and $74.40^{\circ}$ were characteristic peaks of $\mathrm{Cu}_{2} \mathrm{O}$ [23]. In figure 8(6), $2 \theta$ angles $26.68^{\circ}$, $30.92^{\circ}, 33.67^{\circ}, 36.50^{\circ}, 39.13^{\circ}, 41.99^{\circ}, 47.57^{\circ}, 54.58^{\circ}$, $58.76^{\circ}, 62.73^{\circ}$ and $69.58^{\circ}$ were characteristic peaks of $\mathrm{ZnO}$, while $2 \theta$ angles $31.90^{\circ}, 36.99^{\circ}, 53.21^{\circ}, 63.30^{\circ}$, $66.60^{\circ}$ and $87.20^{\circ}$ were characteristic peaks of $\mathrm{ZnO}$ [24]. In figure $8(7), 2 \theta$ angles of $9.69^{\circ}, 12.84^{\circ}$, $23.01^{\circ}, 25.80^{\circ}, 39.13^{\circ}, 27.41^{\circ}, 29.36^{\circ}, 39.19^{\circ}, 45.90^{\circ}$ and $58.82^{\circ}$ were characteristic peaks of $\mathrm{MoO}_{3}$, and $2 \theta$ angles of $26.03^{\circ}, 36.52^{\circ}, 53.79^{\circ}, 65.70^{\circ}$ and $66.66^{\circ}$ were characteristic peaks of $\mathrm{MoO}_{2}$ [25]. In Fig. 8(8), $2 \theta$ angles $34.60^{\circ}, 30.27^{\circ}, 23.01^{\circ}, 43.25^{\circ}, 57.17^{\circ}$ and $62.82^{\circ}$ were characteristic peaks of $\mathrm{CrO}$, and $2 \theta$ angles $24.49^{\circ}, 33.60^{\circ}, 36.20^{\circ}, 41.48^{\circ}, 50.22^{\circ}$ and $54.85^{\circ}$ were characteristic peaks of $\mathrm{Cr}_{2} \mathrm{O}_{3}$ [26]. In Fig. 8(9), $2 \theta$ angles $18.11^{\circ}, 19.76^{\circ}, 21.81^{\circ}, 22.84^{\circ}, 23.97^{\circ}, 28.84^{\circ}$, $31.58^{\circ}, 33.28^{\circ}, 36.96^{\circ}, 37.52^{\circ}, 42.61^{\circ}, 45.09^{\circ}, 49.86^{\circ}$, $56.04^{\circ}$ and $60.27^{\circ}$ were characteristic peaks of $\mathrm{Mn}_{2} \mathrm{O}_{3}$, $2 \theta$ angles $32.92^{\circ}, 35.60^{\circ}$ and $53.21^{\circ}$ were characteristic peaks of $\mathrm{Mn}_{2} \mathrm{O}_{3}$, and $2 \theta$ angles $17.55^{\circ}, 18.02^{\circ}, 28.97^{\circ}$, $32.41^{\circ}, 34.06^{\circ}, 35.31^{\circ}, 44.37^{\circ}, 56.78^{\circ}, 60.02^{\circ}$ and $62.35^{\circ}$ were characteristic peaks of $\mathrm{Mn}_{3} \mathrm{O}_{4}$ [27]. Diffraction peak strength was large, the popularity was sharp, the formation of oxide dispersion was good, increased the catalytic activity of the catalyst. Combined with the results of specific surface area, although the specific surface area of $\mathrm{Cr}_{2} \mathrm{O}_{3} / \gamma-\mathrm{Al}_{2} \mathrm{O}_{3}$ was smaller than the surface of $\gamma-\mathrm{Al}_{2} \mathrm{O}$, but in the $\mathrm{Cr}_{2} \mathrm{O}_{3} / \gamma-\mathrm{Al}_{2} \mathrm{O}_{3}$ catalyst formed active $\mathrm{Cr}_{2} \mathrm{O}_{3}$, improved the catalytic activity, so $\mathrm{Cr}_{2} \mathrm{O}_{3} / \gamma-\mathrm{Al}_{2} \mathrm{O}_{3}$ on coal pyrolysis catalytic cracking effect was the best.

Table 5. Cr element determination results of $\mathrm{Cr}_{2} \mathrm{O}_{3} / \gamma-\mathrm{Al}_{2} \mathrm{O}_{3}$ catalyst (\%)

\begin{tabular}{|c|c|c|c|}
\hline $\begin{array}{c}\text { Load } \\
\text { capacity }\end{array}$ & Elements & $\begin{array}{c}\text { Theoretical } \\
\text { value }\end{array}$ & $\begin{array}{c}\text { Determination } \\
\text { of value }\end{array}$ \\
\hline 1 & 0.68 & 0.66 & 97.06 \\
\hline 5 & 3.42 & 3.00 & 87.72 \\
\hline 8 & 5.47 & 4.43 & 81.04 \\
\hline
\end{tabular}

\section{Determination of Metal Element Loading Amount of Catalyst by ICP-MS}

Table 4 showed the results of metal element loading of $\gamma-\mathrm{Al}_{2} \mathrm{O}_{3}$ catalysts with different metal supports. It can be seen from Table 4, ICP-MS [28] determined metal element, and the actual content and the theoretical content of metal elements had certain difference, that the metal in the process of load had a certain loss, but each metal elements of effective negative rate were over $85 \%$, among them $\mathrm{Cr}_{2} \mathrm{O}_{3} / \gamma-\mathrm{Al}_{2} \mathrm{O}_{3}$ catalyst metal elements $\mathrm{Cr}$ payload rate was as high as $87.72 \%$, which proved more metal oxide was formed on the catalyst carrier, and ensured the activity of catalyst.

Table 5 showed the results of determination of $\mathrm{Cr}$ element in $\mathrm{Cr}_{2} \mathrm{O}_{3} / \gamma-\mathrm{Al}_{2} \mathrm{O}_{3}$ catalyst by ICP-MS. It can be seen from table 5 that with the increase of load, the payload rate decreased. When the load was $1 \%$, the effective load was the highest, and the highest value was $97.06 \%$. The reason was that the pore size of $\gamma-\mathrm{Al}_{2} \mathrm{O}_{3}$ was certain, the loading capacity was small, the solution concentration was low, the metal element Cr was easy to be adsorbed. When the loading capacity increased, the solution concentration was higher, and the adsorption of metal element $\mathrm{Cr}$ was easy to reach saturation, so the loading rate became smaller.

\section{Conclusions}

The liquid yield and gas yield of raw coal pyrolysis were $0.32 \mathrm{~g}$ and $1.58 \mathrm{~g}$, respectively. The maximum total contents of $\mathrm{CO}, \mathrm{H}_{2}$ and $\mathrm{CH}_{4}$ produced by raw coal pyrolysis were $71.40 \%$, respectively.

Different oxides supported $\gamma-\mathrm{Al}_{2} \mathrm{O}_{3}$ catalysts were added to the coal samples for mixed pyrolysis. $\mathrm{Fe}_{2} \mathrm{O}_{3} / \gamma-\mathrm{Al}_{2} \mathrm{O}_{3}$ catalysts made the highest of the tar yield, it was $0.71 \mathrm{~g}$, and which was $134.38 \%$ higher than that of raw coal pyrolysis. $\mathrm{Cr}_{2} \mathrm{O}_{3} / \gamma-\mathrm{Al}_{2} \mathrm{O}_{3}$ catalyst also resulted in the highest gas yield, it was $1.73 \mathrm{~g}$, and which was $9.5 \%$ higher than raw coal. The highest contents of $\mathrm{CO}, \mathrm{H}_{2}$ and $\mathrm{CH}_{4}$ were produced during the pyrolysis of $\mathrm{Cr}_{2} \mathrm{O}_{3} / \gamma-\mathrm{Al}_{2} \mathrm{O}_{3}$ catalyst, which was $87.31 \%$, and the 
pyrolysis condition was $600^{\circ} \mathrm{C}$ for $5 \mathrm{~min} . \mathrm{Cr}_{2} \mathrm{O}_{3} / \gamma-\mathrm{Al}_{2} \mathrm{O}_{3}$ catalyst prepared with $1 \% \mathrm{Cr}_{2} \mathrm{O}_{3}$ support had a good catalytic effect on coal mixed pyrolysis.

The catalyst after being loaded was calcined to form oxide, which cloged the pore channels of the support and lead to a small specific surface area. So the specific surface area of the catalyst had a great influence on the pyrolysis products of the mixture of catalyst and coal, and the larger the specific surface area was, the better the pyrolytic cracking effect was. The specific surface area of $\gamma-\mathrm{Al}_{2} \mathrm{O}_{3}$ was 271.64, the specific surface area of $\mathrm{Cr}_{2} \mathrm{O}_{3} / \gamma-\mathrm{Al}_{2} \mathrm{O}_{3}$ and $\gamma-\mathrm{Al}_{2} \mathrm{O}_{3}$ was similar, which was led to better adsorption of oil and gas molecules and contacted with active sites. The catalytic cracking effect of $\mathrm{Cr}_{2} \mathrm{O}_{3} / \gamma-\mathrm{Al}_{2} \mathrm{O}_{3}$ was more obvious than that of $\gamma-\mathrm{Al}_{2} \mathrm{O}_{3}$, so the catalytic activity of $\mathrm{Cr}_{2} \mathrm{O}_{3}$ was higher. By ICP-MS detection of load metal element content, it found that the load rate was relatively high, and the smaller the load the higher the load rate.

\section{Acknowledgments}

Financial support of this research was provided by Key Laboratory of Coal Resources Exploration and Comprehensive Utilization, Ministry of Land and Resources (Program No.KF2020-10) in P.R. China. Project 51704230 supported by National Natural Science Foundation of China.

\section{Conflict of Interest}

The authors declare no conflict of interest.

\section{Reference}

1. MENG D.X., YUE C.Y., WANG T., CHEN X.L. Evolution of carbon structure and functional group during Shenmu lump coal pyrolysis. Fuel, 287, 1, 2021.

2. GUO X., TANG Y.G., WANG Y.F., EBLE C.F., FINKELMAN R.B., HUAN B.B., PAN X. Potential utilization of coal gasification residues from entrainedflow gasification plants based on rare earth geochemical characteristics. Journal of Cleaner Production, 280, 1, 2021.

3. GAO L.F., LIU X.C., BAI J., et al. Structure and flow properties of coal ash slag using ring statistics and molecular dynamics simulation: Role of $\mathrm{CaO} / \mathrm{Na}_{2} \mathrm{O}$ in $\mathrm{SiO}_{2}-\mathrm{Al}_{2} \mathrm{O}_{3}-\mathrm{CaO}-\mathrm{Na}_{2} \mathrm{O}[\mathrm{J}]$. Chemical Engineering Science, 231, $1,2021$.

4. GAO H.S., ZONG Z.M., LI J.H., KONG L.X., BAI Z.Q., LI W. Characterization of Oxygen-Containing Aromatics in a Low-Temperature Coal Tar. Energy \& Fuels, 31 (1), 283, 2021.

5. YUAN X., QING M.L., MENG L.Q., ZHAO H.B. OneStep Synthesis of Nanostructured $\mathrm{Cu}-\mathrm{Mn} / \mathrm{TiO}_{2}$ via Flame Spray Pyrolysis: Application to Catalytic Combustion of $\mathrm{CO}$ and $\mathrm{CH}_{4}$. Energy \& Fuels, 34 (11), 14447, 2020.
6. HAN D.hH, HU Y.Q., WANG J.S., YAO R., SHAO J.X. Study and Analysis of Influence Factors of Coal Pyrolysis. Coal Technology, 30 (7), 164, 2011.

7. WANG J.H., CHANG L.P., XIE K.C. Study on the pyrolysis and kinetics of coal of wewtern China. Coal Conversion, 32 (3), 1, 2009.

8. ZHANG Q.L., LI F.Y., HUI X.R. LUO M., ZHOU J. Evolution Characteristics of Gas Products in Pyrolysis Process of Low Metamorphic Coal [J]. Coal Conversion, 42 (4), 32, 2019.

9. LIU Q.F., CUI X.N., XU Z.J., ZHENG Q.M., WU Y.K. Main gases and kinetics of coal pyrolysis [J]. Coal Geology \& Exploration, 44 (6), 27, 2016.

10. WANG K.F., QIAN J., SUN F., TIAN Z.Q., GAO J.H., ZHAO G.B. In-situ catalytic conversion of coal pyrolysis gas to nanoporous carbon rods and superior sodium ion storage performance. Fuel, 281, 1, 2020.

11. CHEN Q.L., FANG M.X., CEN J.M., ZHAO Y.F., WANG Q.H., WANG Y.W. Electrostatic precipitation under coal pyrolysis gas at high temperatures. Powder Technology, 362, 1, 2020.

12. ZHENG C.H., LIU X.T., XU X., YAN P., CHANG Q.Y., WANG Y., GAO X. Experimental study on electrostatic removal of high-carbon particle in high temperature coal pyrolysis gas. Proceedings of the Combustion Institute, $\mathbf{3 7}$ (3), 2959, 2019.

13. LI Z., ZHAO X.C., MIAO B.B., JIANG Y.R., ZHAO Y.J. Preparation of Supported $\mathrm{Fe}_{2} \mathrm{O}_{3} / \gamma-\mathrm{Al}_{2} \mathrm{O}_{3}$ Catalyst and Its Performance in Microwave Pyrolysis of Coal. Journal of Materials Science and Engineering, 32 (6), 826, 2014.

14. YAN H., GONG M.G., WANG J.Y., WANG C.P. AntiCarbon Deposition Performance of $\mathrm{Ca}-\mathrm{Mg}$ Catalyst in Coal Tar Catalytic Cracking Process. Acta Petrolei Sinica(Petroleum Processing Section), 36 (04), 832, 2020.

15. ZHANG Y.M., ZOU D., ZHAO Y., ZHONG M., MA F.Y. Effect of bimetallic catalysts on cracking behavior of coal tar model compounds.CIESC Journal, 68 (10), 3805, 2017.

16. MEROUFEL B., ZENASNI M.A., GEORGE B. Valorisation and Modification of Saharan Clay for Removal of $\mathrm{Cu}(\mathrm{II}), \mathrm{Ni}(\mathrm{II}), \mathrm{Co}(\mathrm{II})$ and $\mathrm{Cd}(\mathrm{II})$ from Aqueous Solutions. Polish Journal of Environmental Studies, 29 (2), 1287, 2020.

17. HU N.F., CUI H.T., QIU Z.G. ZHAO L.F., MENG Xi.X., ZHAO Z.Q., AO G.Y. Effect of phosphorus loadings on the performance of $\mathrm{Co}-\mathrm{Mo} / \gamma-\mathrm{Al}_{2} \mathrm{O}_{3}$ in hydrodesulfurization of coal tar. Journal of Fuel Chemistry and Technology, 44 (6), 745, 2016.

18. ZHANG P.W., WANG B., TIAN W.D., YANG S.J, XIAO Y.H. Influences of mixing methods on $\mathrm{CaO} / \mathrm{char}$ steam gasification. Journal of China Coal Society, 41 (8), 2097, 2016.

19. ZHANG L., CHRN J.H., ZHANG L., SHA, X.L., LI Y.H., Fan M. Preparing Mn-CoO-Supported Pyrolysis Coke Catalyst with Plasma and its Application in the SCO Denitration Process. Polish Journal of Environmental Studies, 28 (5), 3323, 2019.

20. LIU W.S., HUANG B.F., LIU L.P., ZHAO H.W., ZHAO S.M., PAN C.L., LIU H.W. Preparation and characterization of supported $\gamma-\mathrm{Fe}_{2} \mathrm{O}_{3}$ coconut shell activated carbon catalyst. Carbon Techniques, 38 (06), 49, 2019.

21. TANG W.D., YANG S.T., YANG H., XUE X.X. Effect of $\mathrm{Co}_{2} \mathrm{O}_{3}$ on Oxidation Induration and Reduction Swelling of Chromium-Bearing Vanadium Titanomagnetite Pellets with Simulated Coke Oven Gas. Metals, 9 (01), 1, 2018. 
22. YU H.F., CHEN C.L., WANG Y.J., LUO M.F. Ozone Decomposition over NiO/Mn3O4 Monolithic Catalysts. Chinese Journal of Applied Chemistry, 36 (06), 698, 2019.

23. LIN M., NA W., YE H.C., HUO H.H., GAO W.G. Effect of different promoters on $\mathrm{CuO}-\mathrm{ZnO} / \mathrm{SBA}-15$ catalytic performance of $\mathrm{CO}_{2}$ hydrogenation to methanol. Journal of Fuel Chemistry and Technology, 47 (10), 1214, 2019.

24. HE Z.M., XIA Y.M., TANG B., JIANG X.F., HUANG Z.Y. Preparation and Photocatalytic Property of $\mathrm{ZnO} / \mathrm{Cu}_{2} \mathrm{O}$ Heterostructured Nanorod Arrays. Chinese Journal of Luminescence, 38 (07), 936, 2017.

25. HUANG P., LIU M., CHANG Q.L. $\mathrm{MoO}_{3} / \mathrm{Al}-\mathrm{SBA}-15$ modified catalyst and its application in coal tar hydrocracking. Journal of Fuel Chemistry and Technology, 48 (09), 1079, 2020.

26. WU T.X., YANG Y.W., CAI Q., SUN Y.M., YU H.B. Catalytic performance of $\mathrm{CrOx} / \mathrm{Al}_{2} \mathrm{O}_{3}$ for dehydrogenation of propane. Natural Gas Chemical Industry, 41 (03), 16, 2016.

27. WANG Z.J., SOHN I. Immobilizing chromium in stainless steel slags with $\mathrm{MnO}$ addition. Journal of the American Ceramic Society, 104 (2), 697, 2021.

28. YE J.M., WU B.L., WANG H., YUAN L.F., LUO C. Determination of fourteen elements residues of catalysts in plastics [J]. Chinese Journal of Analysis Laboratory, 31 (09), 54, 2012. 
